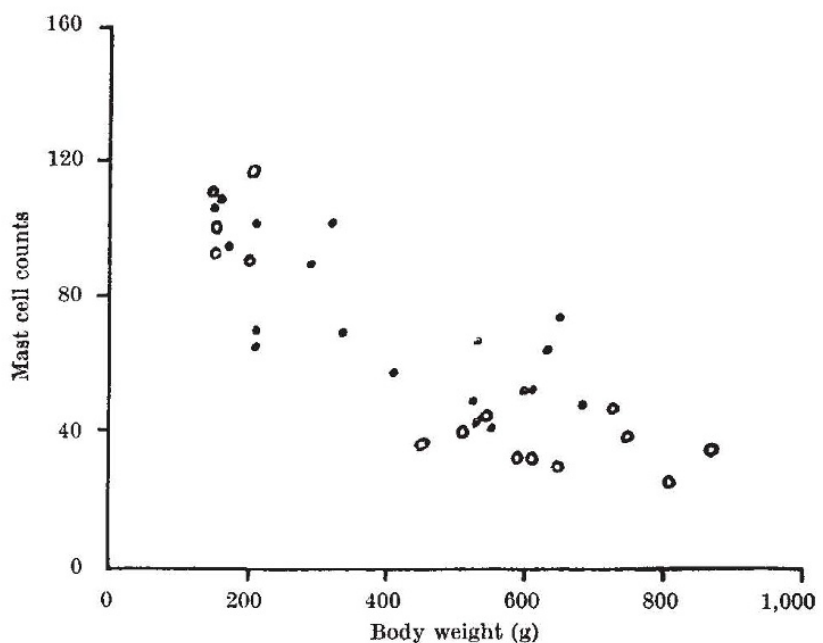

Fig. 1, The relationship between mast cell count and body weight.

When the mast cell counts of the guinea-pigs were plotted against body weight, a rectilinear relationship was found (Fig. 1). The correlation coefficient for the female animals was 0.89 and for the males 0.77. Selye ${ }^{6}$, in his intensive bibliography, presents no constant picture of the mast cell count in the ageing process, and makes no mention of it in guinea-pigs. Because weight gives a reasonable estimate of the age of these animals, my results suggest that there is a significant fall in the omental mast cell count with age within the rango studied.

Department of Physiology,

R. St. J. Buxton

University of Bristol.

${ }^{1}$ Shelley, W. B., and Florence, R., Nature, 191, 719 (1962).

"Cairns, A., and Constantinides, P., Science, 120, 31 (1954).

${ }^{3}$ Koltai, M., Minker, E., and Deak, G., Die Naturwiss., 52, 15 (1965).

4 Harvey, E. B., Anat. Record, 148, 407 (1964).

${ }^{5}$ Constantinides, P., and Rutherdale, J., J. Geront., 12, 264 (1957).

:Selye, H., The Mast Cells (Butterworths, Washington, 1965).

\section{Metabolic Differences between Dietary Liquid Glucose and Sucrose}

IN the fifty years since Higgins ${ }^{1}$ obtained evidence that fructose has a greater tendency to change into fat in the body than has dextrose, more evidence has accumulated, much of it in the past few years, to show that lipid metabolism in man and experimental animals is affected differently by different carbohydrates ${ }^{2-5}$. Recently, it was found that substitution of sucrose for starch in the diet of weanling and three month old rats caused metabolic changes $^{6}$, and that dicts containing sucrose, and more especially fructose, increased plasma cholesterol levels and carcass and liver fat of adult rats compared with diets containing dextrose or liquid glucose or a standard laboratory diet?

Long-term feeding trials in man under strict experimental conditions are difficult, but studios of primates are desirable to investigate further the possible connexion between dietary sucrose and ischaemic heart disease ${ }^{8-10}$. The suscoptibility of baboons to develop atherosclerosis has been demonstrated ${ }^{11}$, and at present we are using mature baboons (Papio anubis $=P$. doguera) for longterm foeding trials in which high earbohydrate diets are being compared. In proliminary studies with a small group of twelve animals, differences have been found between baboons fed liquid glucose and those fed sucrose; the present findings support the accumulating evidence that dietary carbohydrates are not all metabolically equivalent.

Sexually mature animals weighing about $9.5 \mathrm{~kg}$ were fed for 26 wceks on diets containing 74 per cent available carbohydrate, either as spray-dried liquid glucose BPC
Table 1. Measurements on Baboons Fed Liquid Glucose, SUcrose OR CONTROL DIETS FOR 26 WEEKS*

Liquid glueose Sucrose Control

Total serum lipid, mean value $347 \pm 29 \quad 458 \pm 27 \quad 341 \pm 22$

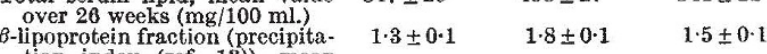

tion index (ref. 13)), mean

value over 26 weeks

Energy value of food Results at end of experiment

Encrgy value of food consumed $122 \cdot 1 \pm 4 \cdot 2 \quad 139 \cdot 1 \pm 8 \cdot 5 \quad 103 \cdot 5 \pm 3 \cdot 1$

$\begin{array}{cccc}\left(\mathrm{kcal} \times 10^{3}\right) & 1.0 \pm 0.57 & 2.2 \pm 0.51 & 2.6 \pm 0.16\end{array}$

$\begin{array}{lrrr}\text { Weight gained }(\mathrm{kg}) & 1 \cdot 0 \pm 0 \cdot 57 & 2 \cdot 2 \pm 0 \cdot 51 & 2 \cdot 6 \pm 0 \cdot 16 \\ \text { Increase in thoracic girth (cm) } & 0 \cdot 3 \pm 1 \cdot 41 & 3 \cdot 5 \pm 1 \cdot 70 & 2 \cdot 6 \pm 1 \cdot 33 \\ \text { Abdominal depot fat + epididy- } & 33 \cdot 6 \pm 7 \cdot 0 & 81.5 \pm 5 \cdot 2 & 38 \cdot 6 \pm 19 \cdot 7\end{array}$

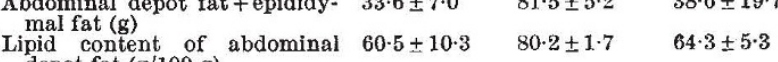

fat $(\mathrm{g} / 100 \mathrm{~g})$

* The values are means and standard errors of means for groups of four mature baboons, two male and two female. Differences between sexes were not significant.

(ref. 12) (an aqueous preparation of partially hydrolysed starch) or as sucrose, or a control diet containing 47 per cent available carbohydrate mainly as starch but with some sucrose (4.5 per cent) and liquid glucose $(4.5$ per cent). The results are summarized in Table 1.

The total serum lipid of the baboons fed the three diets increased during the first 2 weeks, and the increase was greatest in the animals fed sucrose; at the end of the experiment, the total serum lipid in these was significantly higher $(P<0.01)$ than in the animals fed liquid glucose or the control diet. The serum $\beta$-lipoprotein was also significantly higher $(P<0.01)$ in the baboons fed sucrose than in those fed liquid glucose, while the corresponding value in the control group was intermediate.

Although the animals fed sucrose showed trends towards higher food intake, greater weight gain and larger increase in thoracic girth than those fed liquid glucose, the differonces were not statistically significant.

In the animals fed sucrose, the combined weight of abdominal and epididymal fat was significantly greater $(P<0.01)$ than in those fed either of the other diets. The abdominal dopot fat from the animals fod sucrose also contained significantly more lipid $(P<0.01)$ than that from the other animals.

Small atherosclerotic plaques were found in some animals, but their frequency was not related to the diet used and the lesions were apparently of long standing.

Our initial results indicate that, compared with a high liquid glucose diet, a high sucrose diet increases the level of serum lipid, and that this increase is associated with an increase in the amount of abdominal fat deposited. If these results with primates are confirmed in tests with larger numbers they could have implications for human diets.

We thank Dr. G. A. Gresham for examining the aortae at post-mortem.

Beecham Group, Lid.,

R. J. L. AlLeN

Brentford, Middlesex.

\section{BROOK}

R. E. Lister

A. K. SiM

Arthur D. Little, Itd.,

M. H. WARWICK

Musselburgh,

Midlothian, Scotland.

${ }^{1}$ Higgins, H. L., Amer. J. Physiol., 41, 258 (1916).

2 Antar, M. A., and Ohlson, M. A., J. Nutrit., 85, 329 (1965).

${ }^{3}$ Cohen, A. M., and Teitelbaum, A., Amer. J. Physiol., 206, 105 (1964).

4 Lopez, A., Hodges, R. E., and Krehl, W. A., Amer. J. Clin. Nutrit., 18, 149 (1966).

${ }^{5}$ Macdonald, I., Proc. Nutrit. Soc., 23, 119 (1964).

'Al-Nagdy, S., Miller, D. S., Qureshi, R. U., and Yudkin, J., Nature, 209, 81 (1906).

${ }^{7}$ Allen, R. J. L., and Leahy, J. S., Brit. J. Nutrit., 20, 339 (1966).

'Cohen, A. M., Bavly, S., and Poznanski, R., Lancet, ii, 1399 (1961).

- Osancová, K., Hejda, S., and Zvolánková, K., Lancet, i, 494 (1965).

${ }^{30}$ Yudkin, J., Lancet, ii, 4 (1964).

${ }^{11}$ Gresham, G. A., Howard, A. N., McQueen; J., and Bowyer, D. E., Brit. J. Exp. Path., 46, 94 (1965).

${ }^{12}$ British Pharmaceutical Codex 1963, 338 (The Pharmaceutical Press, London, 1963).

${ }^{1 s}$ Heiskell, C. L., Fisk, R. T., Florsheim, W. H., Tachi, A., Goodman, J. H. and Carpenter, C. M., Amer. J. Clin. Path., 35, 222 (1961). 